\title{
Dilemmas Downstream from the Songhua River Spill
}

\section{Lisa $W u, M D$}

On November 13, 2005, an explosion occurred at a petrochemical plant in Jilin City, China; the explosion affected the lives of millions of local and remote residents. A blast occurred at the Jilin Petrochemical Corporation as the result of an obstruction in a processing tower. The blast produced a spill, estimated at 100 tons, of toxic substances into the Songhua River. Five persons were confirmed dead, nearly 70 people were wounded, and over 10,000 residents were evacuated [4]. In the weeks that followed, downstream contamination of water supplies affected residents from rural northeastern China, including Harbin (the region's major city), all the way to neighboring Russia.

According to the Chinese State Environmental Protection Agency (SEPA), the explosion released benzene, aniline, and nitrobenzene into the Songhua River. The amounts of benzene, aniline, and nitrobenzene exceeded the permissible levels in the surface water [3]. Benzene, a component of crude oil, is one of the most commonly used industrial solvents in China. It is also a recognized carcinogen, linked to hematological malignancies that include aplastic anemia and leukemia. Aniline is known to induce methemoglobinemia. While rat studies link aniline to splenic cancer, human studies evaluating the carcinogenic properties, are not definitive. Nitrobenzene, while associated with liver, thyroid, and kidney tumors in animals, has not been studied in humans [1]. The Songhua River serves as the major water supply for the 4 million inhabitants of the city of Harbin, located 200 kilometers downstream from the site of the leak. In order to dilute the pollutants, water flow into the river was increased from the Fengman hydroelectric power station. Based on river flow rates, officials estimated the time of arrival of the toxic front to Harbin and shut off the city's water supply on November 23, 2005. By the time the pollution plume reached Harbin on November 25, 2005, only nitrobenzene continued to exceed permissible levels; aniline and benzene concentrations had declined below permissible levels. Water remained unavailable for 5 days until supplies were declared safe for drinking [3].

The immediate concerns of government officials and residents centered around preventing exposure to toxic chemicals, supplying clean water to residents, and continued monitoring of water quality. SEPA enlisted the help of the United Nations Environment Programme (UNEP) to determine a plan of action. Sampling the river water during the winter months was challenging because there were no available means for sampling the water when the river was frozen. Additionally, nitrobenzene, being heavier than water, sinks to the bottom and accumulates in some locations before moving downstream more slowly. This requires a monitoring of bottom water and the repeating of measurements for an extended period of time. Samples of aquatic organisms, drinking water sources, and ground water supplies will need to be monitored in the upcoming months to account for these effects. In addition, UNEP recommended investigations of air and soil samples along the Songhua River.

Warmer springtime weather leads to changes in river flow dynamics and increased dependence on the Songhua River for agricultural irrigation. As the ice thaws, frozen pollutants may be released as liquids or gases and dense toxins (that may have settled in river depressions) may start to move downstream as the water flow increases. While the river is not used for irrigation of crops during the winter months, in the spring and summer, monitoring of the Songhua River will be necessary to determine if the river water is safe for agricultural use. Plant accumulation studies are also required to ensure the lack of accumulation of toxins in harvested products.

In the wake of the spill, China was targeted with questions about its environmental protection policies, particularly its delay in releasing information to the public. Ten days after the explosion and spill, residents of Harbin were notified of the situation, reportedly to calm the increased panic of residents and rumors of a pending earthquake. Government officials have been decried for an alleged cover-up. China's economic boom over the last 20 years has been coupled with criticism of its loose environmental policies and repeated chemical spills that continue to plague the country. For now, the residents of Harbin have resumed their lives, utilizing the restored water supplies. While the immediate effects of the Songhua River spill have been dampened, close monitoring and time will reveal the true extent of its contamination and health effects.

The author has no potential financial conflicts of interest to report.

\section{REFERENCES}

1. Goldfrank's Toxicologic Emergencies. Seventh Edition. McGraw-Hill. 2002.

2. Muldavin, Joshua. Beyond the Harbin Chemical Spill. International Herald Tribune. 30 November 2005. Available 
from: http://www.iht.com/articles/2005/11/30/opinion/ edmuldavin.php

3. United Nations Environment Programme (UNEP). The Songhua River Spill, China, December 2005. Field Mission Report. Available from: www.unep.fr/pc/apell/disasters/ china_harbin/unepmr.pdf

4. United Nations Environment Programme (UNEP). Awareness and Preparedness for Emergencies on a Local Level (APELL).
Chinese river contamination resulting from petrochemical explosion and toxic spill. Available from: www.unep.fr/pc/apell/ disasters/china_harbin/info.htm

5. Yuan, Fang and Yang Jiandai. Translated by Luisetta Mudie. China's Harbin Slammed for Toxic Spill 'Cover Up'. Radio Free Asia. 29 November 2005. Available from: www.rfa.org/english/news/politics/2005/11/29/china_ harbin/ 